\title{
Complicating Culturally Relevant Pedagogy: Unpacking West African Immigrants' Cultural Identities
}

\author{
Keisha Mclntosh Allen ${ }^{1}$ \\ lesha Jackson \\ Michelle G. Knight \\ Teachers College, Columbia University \\ U. S. A.
}

This study presents findings from a case study of 18 second-and 1.5-generation West African immigrants. We draw upon notions of elusive culture and indigenous knowledges to highlight participants' complex cultural identities and respond to anti-immigration discourses through positioning West African immigrant students as assets in American classrooms. We extend culturally relevant theory in order to reflect the heterogeneity of Black immigrant experiences in challenging simultaneously invisible and stereotypical views of African values, knowledges, and ideologies. We call for practitioners and researchers to attend to Black immigrant youth's hybrid identities, indigenous knowledges, and enactments of cultural competence and socio-political consciousness within curriculum.

\author{
Conceptual and Theoretical Framework \\ Research Design \\ Findings \\ Implications and Conclusions \\ Notes \\ References \\ Appendix A-Participants \\ Appendix B-Interview Protocol
}

From that point on, like my senses, everything around me was so heightened because I, I realized I was Black, but I never put meaning to it....[L]ike in elementary school, I was like, I am NOT Black! I am milk chocolate brown! ... I started not doing art activities because none of the colors were good enough for my skin. I started looking at books and I was like, how come these illustrators can't draw me? ... And then also I realized like the difference in art, like to me, honestly, art is like looking at...African fabrics and like looking at batiks and just looking at the way my mom cooks, and I didn't value art the same way kids in my elementary school and middle school did. And that became a big issue because I hated painting, I hated coloring. But I could make a quilt for you! (laughs) You know, so it was just, it was hard. I felt lost a lot. (Lily², Interview, 10/14/2009) 
First of all, every country [in Africa] has their own, you know, ideologies and just...every country is different. It's not just one continent... it's more than just being West Africa, East Africa, and South Africa, and it's more than just that, you know? (Kaya, Interview, 11/29/2008)

Immigrant students bring into schools a wealth of diverse cultural knowledge, values, and ideologies that are unrecognized or under-utilized in classroom instruction. Furthermore, the current climate of anti-immigrant discourse often positions immigrants as a threat to our country's national and economic security (Fryberg et al., 2011). This is demonstrated in Arizona's Senate Bill 1070, which authorized the arrests of individuals based upon assumed immigration status (O'Leary \& Sanchez, 2011) and House Bill 2281, which banned ethnic studies, calling the programs un-American despite such programs leading to increased student achievement (Orozco, 2011). The "immigrant bashing" (Suarez-Orozco, Roos, \& Suarez-Orozco, 1999, p. 161) occurring in public discourse negatively affects the schooling experiences of immigrant children. As the quotes from Lily and Kaya, participants in our study, indicate, West African immigrants in particular often experience dissonance when American peers and teachers do not understand or appreciate their heterogeneous cultural values, practices, and identities. Although attempts to incorporate immigrant students' cultural ways of knowing have been made in educational scholarship (cf. González, Moll, \& Amanti, 2005; Valdés, 1996), students are frequently marginalized by teaching and curriculum that do not speak to who they are and what they know. The voices of Lily and Kaya remind us that West African immigrant students can feel lost, frustrated, or isolated in the classroom due to such marginalization. In addition to negative academic outcomes, there are also social and emotional consequences that can influence how students conceptualize and negotiate their identities. Although the African immigrant population within the United States has steadily increased since 1980, with 40 percent of African-born Blacks having arrived in the United States between 2000 and 2005 (Kent, 2007), they are a largely understudied and invisible immigrant group in educational literature (Knight, 2011). Within the context of discourses surrounding immigrant students, African immigrants receive little attention, which adds to their invisibility. Much of the current rhetoric and debate over immigration reform focuses on immigrants from Latin American countries, the largest population of immigrants to the United States (O'Leary \& Sanchez, 2011). Consequently, African immigrants are left on the periphery with the potential impact of anti-immigration legislation on this population often overlooked. Furthermore, the extant literature on West African immigrant students has yet to fully explore strategies for supporting them in the classroom (Traoré \& Lukens, 2006).

The experiences of African immigrants within the United States have been fraught with what Ibrahim (2003) describes as a "social imaginary" (p. 58) within which individuals who have not been racialized within their countries of origin are "constructed, imagined, and positioned" (p. 58) as Black. This is evidenced in school achievement data when African immigrants are subsumed within the 
"Black" category of disaggregated test data as well as during social interactions (De Walt, 2011).

We seek to advance the scholarship around African immigrants and broaden conceptualizations of culturally relevant teaching by examining West African immigrants' negotiations of cultural knowledges, values, and ideologies as they make sense of their identities. For West African immigrant students to benefit from pedagogy that is culturally relevant for them, teachers must recognize the diversity among and within people of African descent, particularly in terms of their identities. Towards this goal, we expand the limited number of empirical studies of Black African immigrant students while also affirming the belief that incorporating "diverse forms of knowledge [is] a way to transform education at the school site into learning experiences that are interconnected with the individual and collective reality or realities of the learner" (Dei, 2002). Thus, our intent is to respond to anti-immigration discourses through positioning the diverse knowledges of West African immigrants as assets in American classrooms. Our research questions include: Who and what influences the construction of Black African identities? How are Black African immigrants making sense of their experiences of being Black in America?

\section{Theoretical and Conceptual Framework}

Framing our study as a response to anti-immigration discourses that position immigrants as a threat to American culture, we utilize Dei's (2000; 2002) concept of indigenous knowledges and Yon's (2000) notion of elusive culture. We highlight the cultural values, knowledges, and ideologies that underscore West African immigrants' sense of their shifting cultural and fluid Black African identities. Further, we bring these theories into conversation with LadsonBillings' (1995) conceptualization of culturally relevant pedagogy in order to build upon understandings of its tenets as they relate to challenging anti-immigration discourses.

Ladson-Billings' (1994) seminal study of successful teachers of African American students has forwarded a framework for teaching that assists teachers in understanding diverse groups of students and utilizing their experiences and knowledge as assets within the classroom (Osborne, 1996). These practices, utilized historically by African American teachers, challenge cultural deficit discourses about African American students (Perry, 2003). The first tenet, academic achievement, acknowledges the need for students to acquire literacy, numeracy, and critical thinking skills that go beyond basic competencies. In the second tenet, cultural competence, Ladson-Billings identifies cultural integrity as an outcome of culturally relevant curricula and practice; culturally relevant teachers recognize students' cultural knowledges, values, and ways of being as strengths, facilitating the development of culturally conscious identities. The final tenet, critical consciousness, recognizes the need for students to "read the word 
and the world" (Freire \& Macedo, 1987) and for teachers to incorporate opportunities for socio-political critique in an effort to transform inequitable social structures. The interlocking nature of these tenets are underscored by Perry's (2003) assertion that the overwhelmingly White and middle-class culture of schools requires African American students to develop additional social, political, and cognitive competencies during their schooling. Teaching and learning is further complicated as students' identities are mediated through readings and recognition of identities and personal affiliations with affinity groups and are simultaneously read by others as being a "certain type of person" (Gee, 2000, p.100). These readings of students influence the identities they recognize as available to them as well as the ones they enact (Rubin, 2007) within the cultures of schools and society.

Scholars researching culturally relevant and responsive teaching have articulated varied notions of culture including values, beliefs, worldviews, language, music, and technology (cf. Howard, 2010; Irvine, 2002). Gay (2010) defines culture as "a dynamic system of social values, cognitive codes, behavioral standards, worldviews, and beliefs used to give meaning to our own lives as well as the lives of others" (p. 8). Despite this broad definition, culture is frequently viewed as an identifiable attribute held by racial/ethnic "others" (Yon, 2000), particularly as it is enacted within culturally relevant teaching. Framing culture in this way, however, is problematic as it does not sufficiently recognize culture as messy and difficult to know (Awokoya \& Clark, 2008). Additionally, the scholarship on culturally relevant pedagogy has focused mainly on its enactment with U.S.-born Blacks, and has included little conversation about culturally relevant teaching enacted with other students of color, particularly African immigrants (Goodwin, 2010). Building upon culturally relevant teaching as a framework to explicitly acknowledge the hybrid and fluid cultural identities of African immigrant students is one means of advancing scholarship on the theory and practice of culturally relevant teaching.

Given that much of the scholarship and practice of culturally relevant teaching has focused on African American students as a homogeneous group of learners (cf. Tate, 1995), we draw upon Yon's (2000) concept of culture to add more complex, nuanced understandings of culture within a heterogeneous group of West African immigrants. Yon's (2000) notion of "elusive culture" complicates culturally relevant teaching scholarship and practice by recognizing that fixed attempts to "know" cultures will inevitably diminish educators' abilities to attend to the hybridized and fluid cultural identities young people express. He argues, "paying attention to the elusiveness of culture opens prospects for engaging the ambivalent and contradictory cultural processes of youth even as it makes difficult our capacity to 'know' their cultures" (p. 144). Situated within a Toronto high school with ethnically and racially diverse youth, Yon reveals how the ways in which his participants self-identify do not adhere to conventions between race, culture, and identity such that a Serbian female may choose to identify as Latina because she identifies with the "cultural forms and expressions" (p.128) of that 
racial group. Thus, he argues that culture is complex and unknowable because of the fluid and hybrid ${ }^{3}$ nature of the identities people construct.

While Yon's (2000) work helps us explore hybrid notions of identities, we apply Dei's (2000) concept of indigenous knowledges to center the values, ways of knowing, and ideologies of our participants. Dei challenges the history of exclusion of indigenous knowledges in the academy, arguing that a legacy of colonizing knowledge exists in Western universities. He uses the term indigenous knowledge to emphasize the importance of maintaining cultural values, ideologies, and traditions of indigenous societies through elders imparting this knowledge to younger generations. Rooting indigenous knowledge in an anticolonial articulation of knowing, he argues that African indigenous knowledge exists outside of imposed Western hegemony and further asserts that different knowledges can coexist, concurrently complementing, and conflicting with each other. Thus, we bring together the scholarship on culturally relevant teaching and African Indigenous knowledges to complicate and extend understandings of the cultural identities of Black African immigrants in the United States. We expand the theory and practice of culturally relevant teaching to address the marginalization of Black African immigrants in schools. In doing so, we challenge anti-immigrant discourses by positioning West African immigrants as assets in K12 classrooms.

\section{Research Design}

The research team chose an interpretive, in-depth interview design (Bogdan \& Biklen, 2007) to explore West African immigrants' educational experiences and their civic and political participation in the United States. This allows for inductive thinking to forefront how individuals give meaning to their experiences (Denzin \& Lincoln, 2007). Through the interview questions, the research team was able to engage the participants in conversations regarding their K-16 educational experiences. The participants for the eleven-month case study (November 2008 - October 2009) consisted of a purposeful sample (Bogdan \& Biklen, 2007) of 17 second- and 1.5-generation participants from 8 West African countries: Cameroon, Gambia, Ghana, Guinea, Liberia, Nigeria, Senegal, and Sierra Leone. The participants included nine females and nine males ranging in age from 15-39, who were either in high school, college, or college graduates at the time of the study (Appendix A). 1.5-generation immigrants are defined here as those who arrived in the country of settlement after the age of 6 and before the age of 12; second-generation immigrants are U.S.-born children of at least one foreign-born parent (Rumbaut \& Ima, 1998). Throughout this article, we identify participants collectively as West African but acknowledge that various nationalities, ethnicities, heritages, and experiences are reflected in our data. 
Research team members ${ }^{4}$ recruited participants through educational institutions, community organizations, personal contacts of the researchers, and a snowballing method (Marshall \& Rossman, 2011). Interviews were one-onone, 90-minute, semi-structured, and in-depth and were transcribed verbatim. Semi-structured interviews are useful for studies of how people make sense of particular phenomena or experiences (Bogdan \& Biklen, 2007). The research team used open-ended questions to invite participants to share experiences related to their cultural values and ideologies in order to gain insight into how participants made sense of their culturally specific knowledges (Tilman, 2002) in an American context. Follow-up prompts were utilized for clarification and elaboration (Appendix B). Researchers took field notes after the interviews, highlighting ideas for new questions during research team meetings.

The authors of this paper used constructivist grounded theory (Charmaz, 2006) to analyze transcripts from the 17 interviews. Constructivist grounded theory is based on an inductive, iterative approach to data analysis. We independently line-by-line coded six of the 17 interviews to identify processes described by the study participants. These line-by-line codes were later collapsed into overarching focus codes such as the role of family and the role of education. Notions of an African identity, Black identities, and an American identity were salient topics emerging from the data. We continually returned to the initial interviews, adding and revising codes as we read the remainder. Rather than using preconceived ideas, theories emerged through this process. Analysis was ongoing, as we memoed across transcripts, on individual transcripts, and on literature that spoke to or against emerging theories. This process of coding strengthened the credibility and usefulness of the findings (Charmaz, 2006).

\section{Findings}

The participants in our study have come to understand hybrid Black identities connected to both their West African heritages and American contexts. Our findings highlight the influences of both African and American cultures on the identity negotiations of the West African immigrants interviewed for this study. Their experiences connecting to multiple cultures through language, becoming both African and American, and being present in schools but invisible in curriculum elucidate how they are making sense of their experiences of being Black in America and of the influences on the construction of their Black African identities. Further, we highlight the fact that their cultural practices may not be currently acknowledged or valued in K-16 classrooms, thus extending the theory and application of culturally relevant pedagogy's tenets of critical consciousness and cultural competency to Black African immigrant students. 


\section{Enacting Cultural Competence: Fashioning Black Identities through Language}

Language use within Black communities in the United States has a longstanding history of being at odds with mainstream society (Delpit \& Dowdy, 2008). Acknowledging that African American Vernacular English (AAVE) spoken by native-born Blacks is a legitimate communicative style, researchers such as Delpit and Dowdy (2008) and Smitherman (1977) have long argued that viewing Black dialect as an asset within the classroom is one aspect of being a culturally responsive teacher and is a way to "teach to and through" (Gay, 2010, p.29) the strengths of students of color. Understandings of the connections between language and Black communities within culturally relevant teaching have focused primarily on African American students. Our study examines how our participants demonstrate cultural consciousness as they embody and utilize language in varied contexts.

Thirteen of our participants referenced language as a facet of their or their peers' lived experiences that mediated connections to their home countries as well as to their cultural identities. Participants utilized indigenous languages to maintain or establish connections to their West African heritages and negotiate their experiences with American culture. We focus on language as a salient finding given the politics of English-only and standardized English playing out within schools (Alim, 2007). We also focus on language because of its ability to allow individuals to communicate who they are and what is special about them (Fishman, as cited in Zephir, 1996). Although all of our participants spoke English, understanding how and for what purposes they engaged with their home languages may help us to better support immigrant student populations.

For Alimatu, speaking Pular during weekends home from college or participating in organizations connected to her ethnicity insulated her from feeling marginalized within courses where she perceived students of color to be treated differentially.

Um ba-ba-ba, [...] in terms of my racial identity, not so much because I think one thing I noticed when I got to college is like it wasn't really a factor... I didn't have to think about being Black, being African when I was in New York 'cause I went home and I spoke Pular all the time. (Alimatu, Interview, 12/3/2008)

As she later explains, in the absence of opportunities to speak her mother tongue (Kamwangamalu, 2005), participating in extra-curricular cultural groups such as the African Students Association and Sisters of the Yam, a group for young women of color, helped to sustain her in ways similar to speaking Pular. This is evidenced in her statement that these organizations "helped sustain me as a person, you know, who's like not going home to speak Pular as I was in New York." 
Jake, a second-generation Ghanian immigrant, also reflected how language might connect individuals to their home country and heritage. Despite being born in the United States, Jake identified primarily as African because of his parents. Speaking Twi, the native language of Ghana, for him was about establishing a connection to his Ghanian heritage and thus establishing his West African identity.

I know that I wasn't born there and everything like that, but I just feel like my parents being from there, I'm from there too. Like I just accept it, like you know? I try my best to speak the language, I understand it fluently, speaking it, you know, I have a little bit of an American accent. When I say something, sometimes I'm laughed at. But you know, just the effort, I just try. I don't want to lose that culture. I feel like it's rich... So if I just identify myself as American and just lose that, not even throw the African in there or anything like that, I just feel like it would be lost, the culture, so I want to continue it. (Jake, Interview, 1/17/2009)

As reflected in his statement, although Jake acknowledges that he is American, he identifies strongly with his Ghanian identity and views speaking Twi and other cultural practices as vital components of his identity. This priority is supported by Laroche, Kim, Hui, and Tomiuk's (1998) finding that as individuals acculturate linguistically, there is a loss in ethnic identification. Jake's status as a U.S.-born African who identifies strongly with his Ghanian identity points to the strength of language to serve as a bridge for ethnic identification as well as challenging immigrant discourses that promote an allegiance to one identity (Abu El-Haj, 2011).

Jake's presentation of a firm Ghanian identity also serves as a contrast to the fluid ethnic and national identities expressed by Alimatu:

My life in the U.S. It feels weird. It feels like sometimes like I hear myself speaking and I'm like, Who am I? You know, it's weird. And then like I hear myself speak in Pular and I'm like, Who am I? (laughs) I come here and I'm like, What am I doing? And I'm scrubbing myself with like my fishnet scrub and then like-and it's just it's such, it's moments of like feeling like you're not really you, but then I know whenever I go to Guinea, it's like this is really-you're not really you, you know? So this weird sense of like belonging but not belonging, but then belonging as I'm, I'm proud being a New Yorker, you know? But I'm also proud, the Guinean, you know? (Alimatu, Interview, 12/3/2008)

By describing her Guinean identity as one that can be removed with a cleansing pouf, Alimatu expresses that her ethnic identity, which is only one layer of her identity, is not one that she can easily shed. Alimatu's statement also points to the existential gymnastics some West African immigrants may experience as they engage with language both here and in their country of origin. The fact that these sentiments are felt during discourse events underscores how important language is to Alimatu's identity making. This example challenges Ibrahim's 
(2003) discussion of the hybrid identities the Francophone African youth in his study enacted as they occupied a third space, the place where their cultural values and experiences meet those of Westernized Black culture and co-exist without being in opposition with one another. Instead, Alimatu's experience is more indicative of the power imbalances existing between minority and majority cultures reflected through language (Radhakrishnan, 1996). By acknowledging the dissonance that West African immigrants may experience as they engage in discourse in English and their mother tongue, despite desires to belong to both worlds, we see that language cannot stand alone during ethnic identity development. Efforts toward cultural competence must affirm that the two can coexist but that the messiness of negotiating one's competencies is politically mediated (Yon, 2000).

The centrality of language within Alimatu and Jake's lives points to the ways in which West African immigrants seek opportunities to affirm, develop, or negotiate their cultural identities and view their ability to speak their mother tongue as an asset worth maintaining. Yet, the complexity of narratives such as Alimatu's affirms Yon's (2000) sentiment that identity-making is an investment marked by shifting and changing affiliations. These moments point to the complexity inherent within West African immigrants' negotiations of their hybridized identities as well as the variation of these experiences amongst West African immigrants. They also proffer new ways for thinking about culturally relevant pedagogy by identifying language as a component of cultural integrity. By creating opportunities within the curriculum for students to talk about how language is used within their homes and communities, teachers may strengthen home-school connections, affirm students' cultural identities, and challenge the privileging of English as the only system for organizing and communicating ideas in U.S. schools and the need for immigrants to assimilate into mainstream culture. Such practices reframe bilingualism as a strength instead of a deficiency as is posited in policies such as California's Proposition 227, which ended bilingual education within the state.

\section{Expressing Cultural Competencies: Being both African and American}

Fifteen participants in this study acknowledge a hybrid notion of cultural identity by embracing being both African and American. Unlike Black immigrants who tend to choose national identity labels to distance themselves from negative stereotypes associated with being African American (Okpalaoka, 2009), our participants expressed pride in the ways both their ancestral homes and the United States have shaped their ideologies and identification as African American. Anti-immigration discourse includes an underlying assumption that there is a limit to the amount of social diversity the United States can bear (Suarez-Orozco, Roos, \& Suarez-Orozco, 1999); however, participants in this study express cultural integrity that demonstrates an ability to cull from and contribute to American society, which becomes an avenue for all of us in America 
to learn more about diversity, culture, and tolerance. Gene, a 1.5-generation immigrant from Ghana, articulated this as his worldview: being "Ghanaian but American made." However, the process of developing fluid identities (Rong \& Brown, 2002) also required learning to negotiate the influences and realities of the United States while maintaining strong ties to their West African heritages. We see from the data, as Dei (2000) argues, that "through daily social practice, human societies freely import and adapt customs and ideas from the outside to enrich their accumulated bodies of knowledge" (p. 120). The following quotes best illustrate the adaptation Dei describes. Alimatu, a 1.5-generation participant from Guinea, shared with excitement that during her college years she designed a custom t-shirt that she carried with her. She explained:

I always wanted to have this shirt that's like, it would have the flag of Guinea and then on the back, it would have like the map of, you know, the outline of Africa with like Guinea like outlined, because whenever I say Guinea, it's like, Oh, where's that? And I'm like, Well, you know, right there! (laughs) You know, kind of like a visual, like I wanted to zoom in and this whole-my friend's comment, I was like, Lady $G$, that sounds so cool, and it could be like I'm a G, or like Lady Guinea. (Alimatu, Interview, $12 / 3 / 2008)$

Alimatu's wordplay reflects her connection to her Guinean heritage and the influence of American popular culture, as "G" is slang for gangster or someone who is tough. The nickname and custom designed T-shirt demonstrates what Yon (2000) refers to as "emergent cosmopolitan cultures" (p. 144). Her cultural sense of self is thus hybridized and mediated through her social experiences as a West African in America. This understanding is one she arrived at as a college student who was able to more critically articulate a cultural identity. Ten participants more explicitly expressed a hybridized and fluid perception of their cultural identities. For example, Steve, a second-generation immigrant from Nigeria commented:

We also had the, you know, integration into American society and American culture that was going on just by us being here, you know, and the networks that we developed and the friendships that we developed... as a result of just living and being here... It's like this... bi-focal thing, whatever. It's like okay, you're here but you're still of that, of there, you know? (Steve, Interview, 2/7/2009)

Again, Steve's understanding of his "bi-focal" orientation toward both Nigeria and America came during his adult years. For the 15 participants who made sense of their experiences of being Black in America as a reflective process of recognizing and reconciling what it means to be in but not completely of America, the process typically began after they had lived in America for several years. Participants expressed a focus on both African and American ways of life, as they came to define themselves as both African and American. Alimatu and Steve serve as examples of how knowledges stemming from multiple cultural orientations can coexist (Dei, 2000). Framing immigrants as a threat to American culture relies in 
part on identity boundaries that define group membership based on an American "us" and a foreign "them" (Fryberg et al, 2011). Our participants challenge this dichotomy by understanding themselves as both African and American with both cultures being equally important (Knight, 2011). This hybridization complicates enactments of cultural competence and underscores the need for teachers to genuinely get to know their students beyond monolithic understandings of Blackness that are not inclusive of all of the ethnicities and nationalities within the diaspora. As is argued by Howard (2006), this type of knowledge comes from prolonged and intimate interactions with students and their communities.

\section{Developing Critical Consciousness: Being Invisible or Misrepresented in Curriculum}

While the majority of our participants noted that they felt a sense of belonging to both a West African and American history and heritage, coming to this sense was a process that came at a price for some. Ten participants recalled that their high school experiences either omitted opportunities to study African history or culture or misrepresented Africa in the curriculum. This is particularly salient in light of research that shows students who participated in Arizona's ethnic studies program benefited academically as a result of receiving curriculum and pedagogy that affirmed their cultural histories and realities (Orozco, 2011). Similar to the findings of Traoré and Lukens' (2006) study of African immigrant high school students in the United States, we found that ten participants perceived their teachers and peers to lack knowledge about and respect for their African heritage. Thus, making sense of their experiences of being Black in American classrooms often meant coming to terms with being noticeably absent in the curriculum. Two participants succinctly articulated this. Referring to what was missing from her schooling experiences, Sida, a second-generation participant of Senegalese descent, recalled:

There were no classes about Africa. No one knew nothing, we never talked about it. I mean, we had the traditional American education which was all like focused on our European roots, and anything having to do with Black people was because we were slaves...Any Black history in America started with the first snatch. And then you got the Middle Passage. But forget Africa. Once you got off in the boat, it was like you were in the boat and you're just going like (laughs), so forget about it. (Sida, Interview, 2/14/2009)

Kaya made a very similar point about African American history:

When you talk about African American, you know, rights and just in terms of America, it's interesting that they never really sort of go back and talk about African and relate Africa to that. (Kaya, Interview, 11/29/2008) 
Nine participants acknowledged that their K-12 schooling did not provide opportunities to directly explore or express their racial, national, or cultural identities. When asked if he thought his teachers were aware that he is African, Joseph, who was 15 years old and in high school at the time of the interviews replied, "Yeah, they should know I'm African" but acknowledged that Africa is not represented in the curriculum. Joseph said he expressed being African by "being me, myself." By not integrating and engaging the multiple knowledges and histories of Africa and African immigrants, opportunities to learn about the histories and cultures of people of African descent that enrich the educational experiences of all students are missed.

Ignoring or silencing the cultural identities of West African immigrants in classrooms can have negative social and emotional consequences as well (Traoré, 2003). Tinda shared the shame she and some of her family members felt being West African in America:

But I can see that even now in some of my cousins or even people at school, with the kids that I work with, they're like-when I ask them or I look up their last names, I'm like, Oh, you're from Africa. Where are you from specifically? And you can see them kind of bashfully tell me where they're from, and you can tell there's a sense of shame in that, and that's really unfortunate. (Tinda, Interview, 2/15/2009)

The limited opportunity our participants had to learn about Africa in schools confirms Dei's (2010) assertion that "certain forms of knowledge have traditionally been devalued and denied access into the educational system" ( $p$. 34). Such denial impacts young learners emotionally and academically. Tinda's experience of shame highlights the importance of valuing West African immigrant students' heritages and histories as they develop and negotiate their cultural identities. Too often, our participants' West African identities were not affirmed in their schooling experiences until college. When comparing his high school experiences with those in college, Jake, a second-generation immigrant from Ghana stated:

I just see how people [in college] are just in tune with their backgrounds... and it made me like have an interest, even being interested in my culture more as I went to the university rather than being in high school. And sometimes people would joke on it and, you know, you're ridiculed for...being, you know, different or having that background, you know, sometimes even just like skin color jokes about that. But then me, I never was like bullied as such. I always had to come back strong on like those jokes and things like that, but all I'm saying is that it's like people [in college] are more proud. They seem to be African at school. (Jake, Interview, 1/17/2009)

The idea that West African immigrant students may finish compulsory education in the United States and not "seem to be African" or that they feel ashamed of their heritage while at school reflects their struggle to make sense of being Black 
in America. The struggle is exacerbated by a lack of support from educators who themselves only have negligible awareness of this population (Rong \& Fitchett, 2008) and by the current anti-immigration climate. As evidenced through our participants' experiences of being African in America, knowledge of the varied socio-historical relationships Blacks have to the United States is an essential component of teachers' critical consciousness (Parsons \& Wall, 2011). With this knowledge, teachers are able to challenge anti-immigrant discourses by framing immigrants' histories and contributions inside and outside of the United States as strengths.

\section{Implications and Conclusions}

This study not only adds to the limited number of empirical studies of Black African immigrant students but also seeks to recognize schools as sites of resistance for anti-immigrant discourse. The 1.5- and second-generation West African immigrant participants in our study provide rich understandings of how these individuals have made sense of their experiences being Black in America. Their experiences challenge educators and researchers to re-examine enactments of culturally relevant pedagogy in ways that move beyond subsuming African immigrants into the demographic category "Black" (Awokoya \& Clark, 2008). Broadening the conceptualizations and enactments of culturally relevant pedagogy can challenge anti-immigration discourses by demonstrating that there is not a monolithic immigrant experience in the United States. Our findings suggest that the unique experiences of some West African immigrants can add to the richness of classroom learning environments if teachers capitalize on the knowledges of these students.

The ways our participants negotiate their hybrid and fluid Black identities hold important implications for the theory and practice of culturally relevant pedagogy. These implications include a focus on: (1) increasing opportunities to engage and recognize hybrid and fluid identities in the curriculum, (2) incorporating heritages and histories of people of West African descent in the curriculum as a means of exploring coexisting and contradictory knowledges, and (3) recognizing and then utilizing the cultural competencies and critical consciousness of West African immigrant students in the classroom. These foci intersect as part of expanding notions of culturally relevant teaching.

Educators can work against anti-immigrant discourses by embracing culturally relevant pedagogies and recognizing West African immigrant students as assets in U.S. classrooms and society. Such pedagogies affirm West African immigrant students' knowledge as complementary to American schooling while acknowledging their cultural experiences as varied and diverse. Specifically, participants shared examples of cultural integrity relative to their West African identities and exhibited a critical consciousness about the ways they are racialized and othered while establishing and negotiating hybrid and fluid Black 
identities in the United States. Including the knowledges, values, and ideologies of immigrants in American public schools is particularly important for Black African immigrant students whose histories are often excluded from curriculum. Because anti-immigration discourses do not regard the contributions immigrant students make in American schools, this work requires critically conscious teachers who, through their pedagogy and lesson plans, approach the cultural experiences of immigrants as educationally beneficial in the classroom.

Another aspect of cultural competence that is raised by this research is the need for instructional experiences where West African immigrants' cultural and linguistic practices are positioned as a medium through which African immigrants can maintain cultural integrity. We see from participants such as Alimatu that negotiating linguistic practices is closely linked to her sense of self; her identity is tied to her cultural heritages that she expresses by speaking Pular and English. In order to affirm students' hybrid cultural identities and make schooling experiences more culturally relevant, teachers must be aware of and account for the various cultural values, knowledges, and ideologies West African immigrant students bring to classrooms. Integrating films such as Bronx Princess (Brook, Syeed, \& Williams, 2008) and Elevate (Becker, Buford, Karasawa \& Yoffie, 2011) into the curriculum may be one way of centering the lived experiences West African immigrants in the classroom.

The West African immigrants in this study also possessed a critical consciousness that made them aware of the ways in which they were simultaneously hypervisible because of their heritages and invisible in classrooms that did not include Africa in the curriculum. Our participants Sida and Kaya poignantly articulated that history is sometimes taught in U.S. schools as if African history began with the slave trade. Such awareness allowed participants to critique gaps in their compulsory education and challenge the stereotypical views of African knowledges, values, and ideologies in schools. Engaging students in evaluating media messages about Africa and African people is one strategy that not only challenges deficit discourses about African immigrants, but also supports youths' critical engagement with information.

Our findings have expanded notions of the theory and practice of culturally relevant teaching. Of particular significance are the ways in which West African immigrant students extend the tenets of cultural competence and critical consciousness to challenge discourses surrounding Black immigrant students. Our findings demonstrate how West African immigrant students come to schools with a wealth of cultural competencies and a critical consciousness situated within African and American knowledges, values, and ideologies that are seldom juxtaposed and incorporated into classroom practice. Further research on Black immigrants is needed to address culturally relevant teaching practices for the increasing population of Black African immigrants globally. 


\section{Notes}

1. Authors are listed alphabetically and reflect equal contribution in the drafting of this manuscript.

2. Pseudonyms have been used to maintain participant confidentiality.

3. In referencing hybrid identities, we mean identities that are composed of individuals' multiple social identifications and fluid in the sense that identities are always changing as we interact with others (Rubin, 2007).

4. Research team members who recruited study participants and conducted the interviews include Michelle Knight, Ramatu Bangura, and Vaughn Watson.

\section{References}

Abu El-Haj, T. R. (2011). "The beauty of America": Nationalism, education, and the war on terror. Harvard Educational Review, 80(2), 242-274.

Alim, H. S. (2007). Critical hip-hop language pedagogies: Combat, consciousness, and the cultural politics of communication. Journal of Language, Identity, and Education, 6(2), 161-176.

Awokoya, J. T., \& Clark, C. (2008). Demystifying cultural theories and practices. Multicultural Education, 16(2), 49-58.

Becker, M., Buford, A., Karasawa, C. \& V. Yoffie (Producers), \& Buford, A. (Director). (2011). Elevate [Motion picture]. United States: ESPN Films.

Bogdan, R. C., \& Biklen, S. K. (2007). Qualitative research for education: An introduction to theories and methods (5th ed.). Needham Heights, MA: Allyn \& Bacon.

Brook, Y., Syeed, M., \& Williams, M. (Producers), \& Brook, Y. \& Syeed, M. (Directors). (2008). Bronx Princess [Motion picture]. United States: Highbridge Pictures LLC and Independent Television Services.

Charmaz, K. (2006). Constructing grounded theory: A practical guide through qualitative analysis. London, UK: Sage.

Dei, G. J. S. (2000). Rethinking the role of Indigenous knowledges in the academy. International Journal of Inclusive Education, 4(2), 111-132.

Dei, G. J. S. (2002). Learning culture, spirituality and local knowledge: Implications for African schooling. International Review of Education, 48(5), 335-360.

Dei, G. (2010). Teaching Africa. Dordrecht, The Netherlands: Springer. 
Delpit, L. D., \& Dowdy, J. K. (2008). The skin that we speak: Thoughts on language and culture in the classroom. New York: New Press.

De Walt, P. S. (2011). In search of an authentic African American and/or Black identity: Perspectives of first generation U.S.-Born Africans attending a predominantly White institution. Journal of Black Studies, 42(3), 479-503.

Denzin, N. K., \& Lincoln, Y. S. (2007). Introduction: The discipline and practice of qualitative research. In N. K. Denzin \& Y. S. Lincoln (Eds.), The Sage handbook of qualitative research (3rd ed., pp. 1-43). Thousand Oaks, CA: Sage.

Freire, P., \& Macedo, D. P. (1987). Literacy: Reading the word \& the world. South Hadley, MA: Bergin \& Garvey.

Fryberg, S. A., Stephens, N. M., Covarrubias, R., Markus, H. R., Carter, E. D., Laiduc, G. A., \& Salido, A. J. (2011). How the media frames the immigration debate: The critical role of location and politics. Analyses of Social Issues and Public Policy. 10.1111/j.1530-2415.2011.01259.x

Gay, G. (2010). Culturally responsive teaching: Theory, research, and practice (2nd ed.). New York: Teachers College Press.

Gee, J. P. (2000). Identity as an analytic lens for research in education. Review of Research in Education, 25(1), 99-125.

González, N., Moll, L. C., \& Amanti, C. (2005). Funds of knowledge: Theorizing practice in households, communities, and classrooms. Mahwah, NJ: Lawrence Erlbaum.

Goodwin, A. L. (2010). Curriculum as colonizer: (Asian) American education in the current U.S. context. Teachers College Record, 112(12), 3102-3138.

Howard, G. R. (2006). We can't teach what we don't know: White teachers, multiracial schools (2nd ed.). New York: Teachers College Press.

Howard, T. C. (2010). Why race and culture matter in schools: Closing the achievement gap in America's classrooms. New York: Teachers College Press.

Ibrahim, A. (2003). Marking the unmarked: Hip-hop, the gaze \& the African body in North America. Critical Arts, 17(1-2), 52-70.

Irvine, J. J. (2002). African American teachers' culturally specific pedagogy: The collective stories. In J. J. Irvine (Ed.), In search of wholeness (pp. 139146). New York: Palgrave.

Kamwangamalu, N. M. (2005). Mother tongues and language planning in Africa. TESOL Quarterly, 39(4), 734-738.

Kent, M. M. (2007). Immigration and America's Black population. Washington, DC: Population Reference Bureau. 
Knight, M. (2011). It's already happening: Learning from civically engaged transnational immigrant youth. Teachers College Record, 113(6), 12751292.

Ladson-Billings, G. (1994). The dreamkeepers. San Francisco, CA: Jossey-Bass.

Ladson-Billings, G. (1995). Toward a theory of culturally relevant pedagogy. American Educational Research Journal, 32, 465-491.

Laroche, M., Kim, C., Hui, M. K., \& Tomiuk, M.A. (1998). Test of a nonlinear relationship between linguistic acculturation and ethnic identification. Journal of Cross-Cultural Psychology, 29, 418-433.

Marshall, C., \& Rossman, G. B. (2011). Designing qualitative research. Los Angeles, CA: Sage.

Okpalaoka, C. L. (2009). "You don't look like one, so how are you African?" How West African immigrant girls in the U.S. learn to (re)negotiate ethnic identities in home and school contexts. (Unpublished Dissertation), Ohio State University.

O'Leary, A. O., \& Sanchez, A. (2011). Anti-immigrant Arizona: Ripple effects and mixed immigration status households under "policies of attrition" considered. Journal of Borderlands Studies, 26(1), 115-133.

Orozco, R. A. (2011). 'It is certainly strange': Attacks on ethnic studies and whiteness as property. Journal of Education Policy, 26(6), 819-838.

Osborne, A. B. (1996). Practice into theory into practice: Culturally relevant pedagogy for students we have marginalized and normalized. Anthropology \& Education Quarterly, 27(3), 285-314.

Parsons, E. C., \& Wall, S. (2011). Unpacking the critical in culturally relevant pedagogy: An illustration involving African Americans and Asian Americans. In L. Scherff \& K. Spector (Eds.), Culturally relevant pedagogy: Clashes and confrontations (pp. 15-34). Lanham, MD: Rowman \& Littlefield Education.

Perry, T. (2003). Up from the parched earth: Toward a theory of AfricanAmerican achievement. In T. Perry, C. Steele \& A. G. Hilliard (Eds.), Young, gifted, and Black: Promoting high achievement among AfricanAmerican students (pp. 1-10). Boston, MA: Beacon Press.

Radhakrishnan, R. (1996). Diasporic mediations: Between home and location. Minneapolis, MN: University of Minnesota Press.

Rong, X. L., \& Brown, F. (2002). Socialization, culture, and identities of Black immigrant children: What educators need to know and do. Education and Urban Society, 34(2), 247-73.

Rong, X. L., \& Fitchett, P. (2008). Socialization and identity transformation of Black immigrant youth in the United States. Theory into Practice, 47, 3542. 
Rumbaut, R. G., \& Ima, K. (1998). The adaptation of Southeast Asian refugee youth: A comparative study. Washington, DC: U.S. Office of Refugee Resettlement.

Rubin, B. C. (2007). Learner identity amid figured worlds: Constructing (in)competence at an urban high school. The Urban Review 39(2), 217249.

Smitherman, G. (1977). Talkin and testifyin: The language of Black America. Boston, MA: Houghton Mifflin.

Suarez-Orozco, M., Roos, P. D., \& Suarez-Orozco, C. (1999). Cultural, educational, and legal perspectives on immigration: Implications for school reform. In Jay P. Herbert (Ed), Law and School Reform: Six Strategies for Promoting School Success (pp. 160-204). New Haven, CT: Yale University Press.

Tate, W. F. (1995). Returning to the root: A culturally relevant approach to mathematics pedagogy. Theory into Practice, 34(3), 166-173.

Tilman, L. C. (2002). Culturally sensitive research approaches: An AfricanAmerican perspective. Educational Researcher, 31(9), 3-12.

Traoré, R. (2003). African students in America: Reconstructing new meanings of "African American" in urban education. Intercultural Education, 14(3), 243254.

Traoré, R., \& Lukens, R. J. (2006). This isn't the America I thought I'd find: African students in the urban U.S. high school. Lanham, MD: University Press of America.

Valdés, G. (1996). Con respeto: Bridging the distances between culturally diverse families and schools: An ethnographic portrait. New York: Teachers College Press.

Yon, D. A. (2000). Urban portraits of identity: On the problem of knowing culture and identity in intercultural studies. Journal of Intercultural Studies, 21(2), 143-157.

Zéphir, F. (1996). Haitian immigrants in Black America: A sociological and sociolinguistic portrait. Westport, CT: Bergin \& Garvey. 


\section{Appendix A}

\section{Participants}

\begin{tabular}{|c|c|c|c|c|c|}
\hline Name & Gender & $\begin{array}{l}\text { African } \\
\text { Country }\end{array}$ & Generation & $\begin{array}{l}\text { Language(s) } \\
\text { Spoken in the } \\
\text { Home }\end{array}$ & $\begin{array}{l}\text { Language(s) } \\
\text { Spoken by } \\
\text { Participant }\end{array}$ \\
\hline Lily & Female & $\begin{array}{l}\text { Sierra } \\
\text { Leone }\end{array}$ & $2^{\text {nd }}$ & $\begin{array}{c}\text { Creole (English } \\
\text { Creole) } \\
\text { English }\end{array}$ & English \\
\hline Kaya & Female & Liberia & $2^{\text {nd }}$ & $\begin{array}{l}\text { Creole } \\
\text { Spanish } \\
\text { English }\end{array}$ & English \\
\hline Alimatu & Female & Guinea & 1.5 & $\begin{array}{l}\text { Pular } \\
\text { French } \\
\text { English }\end{array}$ & $\begin{array}{l}\text { Pular } \\
\text { French } \\
\text { English }\end{array}$ \\
\hline Jake & Male & Ghana & $2^{\text {nd }}$ & $\begin{array}{c}\text { Twi } \\
\text { English }\end{array}$ & $\begin{array}{c}\text { Twi } \\
\text { English }\end{array}$ \\
\hline Gene & Male & Ghana & 1.5 & $\begin{array}{c}\text { Twi } \\
\text { English }\end{array}$ & $\begin{array}{c}\text { Twi } \\
\text { English }\end{array}$ \\
\hline Sida & Female & Senegal & $2^{\text {nd }}$ & $\begin{array}{c}\text { Wolof } \\
\text { Creole (Haitian } \\
\text { Creole) } \\
\text { French } \\
\text { English }\end{array}$ & English \\
\hline Joseph & Male & Ghana & $2^{\text {nd }}$ & $\begin{array}{l}\text { Twi } \\
\text { Ga } \\
\text { English } \\
\text { Ewe }\end{array}$ & English \\
\hline Jason & Male & Ghana & $2^{\text {nd }}$ & $\begin{array}{c}\text { Twe } \\
\text { Ga } \\
\text { Ewe } \\
\text { English }\end{array}$ & $\begin{array}{c}\text { Twe } \\
\text { Ga } \\
\text { Ewe } \\
\text { English }\end{array}$ \\
\hline Tinda & Female & Gambia & 1.5 & $\begin{array}{c}\text { Wolof } \\
\text { English }\end{array}$ & $\begin{array}{l}\text { Wolof } \\
\text { English }\end{array}$ \\
\hline Susan & Female & Ghana & 1.5 & $\begin{array}{c}\text { Twi } \\
\text { English }\end{array}$ & $\begin{array}{c}\text { Twi } \\
\text { English }\end{array}$ \\
\hline Steve & Male & Nigeria & $2^{\text {nd }}$ & $\begin{array}{l}\text { English } \\
\text { Yoruba }\end{array}$ & $\begin{array}{l}\text { English } \\
\text { Yoruba }\end{array}$ \\
\hline
\end{tabular}




\begin{tabular}{|c|c|c|c|c|c|}
\hline Name & Gender & $\begin{array}{c}\text { African } \\
\text { Country }\end{array}$ & Generation & $\begin{array}{c}\text { Language(s) } \\
\text { Spoken in the } \\
\text { Home }\end{array}$ & $\begin{array}{c}\text { Language(s) } \\
\text { Spoken by } \\
\text { Participant }\end{array}$ \\
\hline Maureen & Female & Ghana & 1.5 & $\begin{array}{c}\text { Twi } \\
\text { English }\end{array}$ & $\begin{array}{c}\text { Twi } \\
\text { English }\end{array}$ \\
\hline Lisa & Female & Ghana & 1.5 & $\begin{array}{c}\text { Twi } \\
\text { English } \\
\text { Twi }\end{array}$ & $\begin{array}{c}\text { English } \\
\text { Tiwo }\end{array}$ \\
\hline Male & Ghana & $2^{\text {nd }}$ & $\begin{array}{c}\text { English } \\
\text { English }\end{array}$ \\
\hline Yema & Male & Cameroon & $2^{\text {nd }}$ & $\begin{array}{c}\text { French } \\
\text { English } \\
\text { Bafong }\end{array}$ & $\begin{array}{c}\text { French } \\
\text { English }\end{array}$ \\
\hline Ade & Female & Nigeria & $2^{\text {nd }}$ & $\begin{array}{c}\text { Wolof } \\
\text { English }\end{array}$ & $\begin{array}{c}\text { Wolof } \\
\text { English }\end{array}$ \\
\hline
\end{tabular}

Appendix B

Rendering Visible the Civic and Political Incorporation of African Immigrants Interview Protocol:

\section{5-Generation and 2nd-Generation African Immigrants}

\section{Background}

1. What is your name?

2. What would you like me to call you?

3. Where are you from?

4. When and where were you born?

5. Where is your family from?

6. What languages are spoken in your home?

7. How many people lived in your household, including yourself while you were you growing up?

8. What was the other residents' relationship to you?

9. Were any of them U.S. citizens? 
10. When did your parents move here?

11. What were your parents hoping for when they moved here?

12. In what ways are they experiencing those hopes?

13. What message(s) did you receive from your family about education?

14. Can you talk a bit about what it was like growing up in [city in the U.S.]?

15. Can you talk about any activities you were involved in growing up?

a. Why did you choose to participate in these activities?

b. What was your participation like in these activities?

c. Was your participation required or voluntary?

d. Were any of these related to your racial/national/ cultural identity?

e. Were any of these activities related to civic and/or political participation?

f. Who else was involved in these activities?

g. What was their participation like?

h. Were they local, national or international in scope?

i. What was the purpose of these activities?*

\section{Education}

Prior to immigrating to the U.S (for 1.5-generation participants only).

16. Can you tell me about your education experiences prior to immigrating to the U.S.?

17. Please tell me about a typical school week prior to immigrating to the U.S.

18. In what ways are your educational experiences typical of your [generation] African peers?

a. In what ways are your educational experiences atypical of your [generation] African peers?

19. How would you characterize the racial/ ethnic/ gender make up of your school?

20. Do you think that teachers (other school personnel) treat girls and boys the same way or differently? Can you give some examples?

21. What courses have you taken that are related to civics/ politics prior to coming to the U.S.?

a. Were there opportunities in these classes to discuss your racial/national cultural identity?

b. If so, please tell me about these opportunities.

c. If not, why do you think these opportunities did not exist? 
22. How was the U.S. described in your schooling prior to immigrating to the United States?

23. Can you talk about any of the extra-curricular activities you participated in while in school?

a. Why did you choose to participate in these activities?

b. What was your participation like in these activities?

c. Was your participation required or voluntary?

d. Were any of these related to your racial/national/ cultural identity?

e. Were any of these activities related to civic and/or political participation?

f. Who else was involved in these activities?

g. What was the nature of their involvement?

h. Were they local, national or international in scope?

24. In what ways do you see education in society influencing civic and/or political participation in Africa?

25. If you could change anything about your schooling, what would you change?

\section{U.S. focused questions...}

26. Can you share some memories of your schooling experiences?

a. Can you share some memories of schooling experiences outside of the United States?

27. What was your last level of schooling completed?

28. How would you characterize the racial/ ethnic/ gender make up of your school(s)?

29. Did you see any differences (race/ ethnicity/ gender/ nationality) in how the different groups were treated in the school? If yes, can you give an example?

30. Can you describe a person or relationship in the schooling context that influenced your perceptions of civic and/or political participation?

31. Can you talk about any of the extra-curricular activities you participated in while in school?

a. Why did you choose to participate in these activities?

b. What was your participation like in these activities?

c. Was your participation required or voluntary?

d. Were any of these related to your racial/national/ cultural identity?

e. Were any of these activities related to civic and/or political participation?

f. Who else was involved in these activities?

g. What was the nature of their involvement? 
h. Were they local, national or international in scope?

32. What courses have you taken that are related to civics/ politics?

a. Why did you take these courses?

b. Were there spaces in these classes to discuss your racial/national/ cultural identity?

c. If so, in what ways?

d. How was Africa discussed in your U.S. schooling?

e. How was your family's country of origin discussed in your U.S. schooling?

33. In what ways do you see education in society influencing civic and/or political participation in the U.S.?

34. In what ways did schooling influence your thinking of what it means to be a citizen (U.S./ citizen of your family's country of origin)?

35. If you could change anything about your schooling, what would you change?

\section{Civic/ Political}

36. When you think of civic participation, what comes to mind?

37. Can you share a story about a particular civic event (court case, news story, protest, gentrification, global warming, antiwar, Eid, etc.) that encouraged you to participate in civic activities in the U.S.?

a. How did you become involved in this activity?

b. Why did you choose to participate in this activity?

c. What was your participation like in these activities?

d. How often do you participate

e. Was your participation required or voluntary?

f. Tell me about the ways that this particular activity allows you to express your national/cultural/racial/religious heritage?

g. Who else was involved in these activities?

h. What was the nature of their involvement?

i. Were they local, national or international in scope?

j. How does your participation in this activity compare to that of your peers?

k. How does your participation in these activities compare to that of your parents?

38. When you think of participating in politics, what comes to mind?

39. Can you give an example about a particular instance that made you feel like you participated in politics in the U.S., or your country of origin? 
a. How did you become involved in this activity?

b. Why did you choose to participate in this activity?

c. What was your participation like in these activities?

d. How often do you participate

e. Was your participation required or voluntary?

f. Tell me about the ways that this particular activity allows you to express your national/cultural/racial/religious heritage?

g. Who else was involved in these activities?

h. What was the nature of their involvement?

i. Were they local, national or international in scope?

j. How does your participation in this activity compare to that of your peers?

k. How does your participation in these activities compare to that of your parents?

40. How closely do you follow current events in the U.S.?

a. Through what medium(s) do you follow these events?

b. What political issues are important to you?

c. What civic issues are important to you?

41. In what ways do you feel that participation in civic and political activities addresses these civic and political issues?

42. What are some of the specific ways you get and share information about politics or civic life (activities, events, etc.)?

43. In what ways do you use technology (internet, text messaging) to get and share information about politics and/or civic life (activities, events, follow current events, network with the community, etc.)?

a. Why do you choose to utilize technology in these ways?

b. What is the nature of your participation?

c. How often do you use technology?

d. With whom are you using technology (online messaging, sending text messages, etc.)?

e. Were your activities local, national, or international in scope?

44. Can you tell me about how the interaction within the workplace/other institutions (national/cultural/racial/religious/community) may have encouraged you to become involved in politics?

45. Can you give us an example about a particular instance in which anyone you know, or a candidate you follow or admire, participated in politics in the U.S?

a. Is that person involved on the local, regional, or national level? 
46. Have you contemplated going into politics? If yes, what would you like to do?

47. Can you share about a recent conversation you had about the 2008 U.S. presidential election.

48. Can you share about the ways in which you have participated in the 2008 U.S. presidential election?

\section{$\underline{\text { Transnationalism }}$}

49. When you think of Africa what comes to mind?

50. What is life like here for you in the United States?

51. How would you characterize the racial/ national/ ethnic make-up of the community you currently live in?

a. How would characterize your relationships with people in your community?

52. What was communicated to you from the school system/ parents/ community members about your rights/privileges/ responsibilities to the U.S./ to Africa/ to your country of origin?

53. Can you tell me about your interactions with other Africans or those from your country of origin here in the U.S.?

a. Can you describe a daily/ weekly/ monthly interaction?

54. Can you tell me about your interactions with communities in your country of origin or Africa?

a. Can you describe a daily/ weekly/ monthly interaction?

55. Can you share a story about your attempts to stay connected to communities in your family's country of origin?

56. Do you provide support for relatives in Africa?

a. If yes, how often do you provide this support?

b. When did you begin to provide support?

c. If on a regular basis, how often do you provide support?

d. If the support is monetary, for what purpose is the money to be used?

57. Do you provide support for relatives in the U.S.?

a. If yes, how often do you provide this support?

b. When did you begin to provide support?

c. If on a regular basis, how often do you provide support?

d. If the support is monetary, for what purpose is the money to be used?

58. In what ways does the existence or size of an African community play a role in where you choose to live now or move in the future? 
59. How closely do you follow current events in Africa or your country of origin?

a. Through what medium(s) do you follow these events?

b. What political issues in Africa are important to you?

c. What civic issues in Africa are important to you?

60. What are some of the specific ways you get and share information about politics or civic life (activities, events, etc.) in Africa or your country of origin?

61. In what ways do you use technology (internet, text messaging) to get and share information about politics and/or civic life (activities, events, follow current events, network with the community, etc.) in Africa or your country of origin?

a. Why do you choose to utilize technology in these ways?

b. What is the nature of your participation?

c. How often do you use technology?

d. With whom are you using technology (online messaging, sending text messages, etc)?

e. Were your activities local, national, or international in scope?

62. Can you give us an example about a particular instance in which anyone you know, or a candidate you follow or admire, participated in politics in Africa or your country of origin?

a. Is that person involved on the local, regional, or national level?

63. Can you share a story of a recent piece of clothing, art or music that you owned or used that you feel expresses your cultural heritage?

a. What other items do you own or use that express your cultural heritage?

b. What types of media do you use that you feel represents your cultural heritage such as television, music, internet, books or movies?

64. Can you describe any business ventures you engage in between the U.S. and Africa?

a. If you do not participate in these activities do you plan to do so in the future?

65. How do you think the immigration generation influences professional opportunities for African immigrants?

66. What does your level of income allow you to do? What limitations do your level of income place on your activities?

67. What is your current level of income?

$\$ 10,000-\$ 14,999$

$\$ 15,000-\$ 19,999$

$\$ 20,000-\$ 24,999$

$\$ 25,000-\$ 29,999$

$\$ 30,000-\$ 34,999$ 


$\$ 35,000-\$ 39,999$
$\$ 40,000-\$ 44,999$
$\$ 45,000-\$ 49,999$
$\$ 50,000-\$ 54,999$
$\$ 55,000-\$ 59,999$
$\$ 60,000-\$ 64,999$
$\$ 65,000-\$ 69,999$
$\$ 70,000-\$ 74,999$
$\$ 75,000-\$ 79,999$
$\$ 80,000-\$ 84,999$
$\$ 85,000$ and above
don’t know

68. How do you think your level of income influences your civic and political participation?

69. How does your income level compare to others in your immigrant generation?

\section{Generation/ familyl home}

70. What languages are spoken in your home?

71. How many people live in your household, including yourself?

72. What are the other residents' relationship to you?

73. Are any or all of them U.S. citizens?

74. How do your children see their national/ cultural/ racial heritage?

a. If applicable, how do you share your African cultural heritage with your children?

75. Please share a story of a time you noticed difference in your family based on generation (1st, 2nd, 1.5th).

76. What are some of the different messages you've received from family about civic and political participation across generations?

\section{$\underline{\text { Closing }}$}

77. Are there additional clarifications or points you want to add about African immigrants' civic and political participation that we did not discuss? (questions, clarifications, extensions) 
Vol. 14, No. 2

*indicates possible prompt questions 